\title{
Depression and suicidality among Bangladeshi students: Subject selection reasons and learning environment as potential risk factors
}

\author{
Najmuj Sakib $^{1,2}$ | Merajul Islam ${ }^{1,3}$ | Md. Syeed Al Habib ${ }^{1,4}$ | A. K. M. Israfil Bhuiyan ${ }^{1}$ | \\ Md. Mahbub Alam ${ }^{1,5}$ | Noshin Tasneem ${ }^{1,6}$ | Moazzem Hossain ${ }^{1,7}$ | \\ Sheikh Mohammed Shariful Islam ${ }^{8}$ (D) | Mark D. Griffiths ${ }^{9}$ | Mohammed A. Mamun ${ }^{1,10}$ (i) \\ ${ }^{1}$ Centre for Health Innovation, Networking, Training, Action and Research - Bangladesh, Dhaka, Bangladesh \\ ${ }^{2}$ Department of Microbiology, Jashore University of Science and Technology, Jashore, Bangladesh \\ ${ }^{3}$ Jalalabad Ragib Rabeya Medical College, Sylhet, Bangladesh \\ ${ }^{4}$ Department of Biochemistry and Molecular Biology, Mawlana Bhashani Science and Technology University, Tangail, Bangladesh \\ ${ }^{5}$ Department of Nutrition and Food Science, University of South Asia, Dhaka, Bangladesh \\ ${ }^{6}$ Department of Computer Science and Engineering, Jahangirnagar University, Dhaka, Bangladesh \\ ${ }^{7}$ Institute of Allergy and Clinical Immunology of Bangladesh, Dhaka, Bangladesh \\ ${ }^{8}$ Institute for Physical Activity and Nutrition, School of Exercise and Nutrition Sciences, Deakin University, Melbourne, Victoria, Australia \\ ${ }^{9}$ Department of Psychology, Nottingham Trent University, Nottingham, UK \\ ${ }^{10}$ Department of Public Health and Informatics, Jahangirnagar University, Dhaka, Bangladesh
}

\begin{abstract}
Purpose: This study examined the role of subject-selection reasons and learning environment factors in students' depression and suicidality.

Design and Methods: This study surveyed 960 students from five different Bangladeshi universities using questions concerning socio-demographics, lifestyles, subject-selection reasons, learning and academic environment, suicidal behaviors, and Bangla Patient Health Questionnaire.

Findings: Approximately half of the participants were depressed (47.7\%), and just over a quarter had past-year suicidality (28.5\%). Risk factors for both depression and suicidal behavior included not studying at their desired institute, selecting subjects based on future career prospects (rather than choosing what they want to study), not having a study-friendly and research-friendly environment, and unsupportive teachers.

Practical Implications: The findings will help in formulating policies for educational institutions as well as providing benchmark data for further studies.
\end{abstract}

Keywords: Depression; Suicidal behaviors; Subject selection reasons; Learning and academic environment; Bangladeshi university students. 


\section{Introduction}

Skilled graduates are much needed for a country's prosperity and continued workforce. However, before entering the competitive job market, there is competition for tertiary education (Rafi et al., 2019; Mamun et al., 2020a). More specifically, students have to undergo intense competition against other prospective students to enroll in universities. For example, in Bangladesh (where the present study was carried out) only $15 \%$ of the total eligible candidates manage to receive tertiary education (i.e., in 2017, there were approximately 50,000 university places for over 800,000 qualified students) (Trines, 2019). Bangladeshi students are eligible for tertiary education if they pass the higher secondary school certificate exam with a good grade point average. Students who fail to qualify in the highly competitive pre-university admission tests to public universities have no option but to apply to private universities.

However, despite being costlier to attend, many private universities in Bangladesh do not have the requisite infrastructure and resources to provide quality education at the tertiary level (Billah, 2019). Some students who fail to get a place at a public university wait a year to retake the pre-university admission test. In this case, the subject the student gets to study is determined by the university rather than their own choice. Whether students are admitted first or second time around, they are unable to rotate subjects and have to stick with the one they initially chose or the one allotted to them. Consequently, students may end up studying subjects they do not want to do and which they find uninteresting, and persists during the whole period of academic study. For some students, this can lead to poor grades and performance, academic probation, psychological distress, and poor coping resilience - factors that may be common mediators of mental health illnesses such as depression (Storrie, Ahern, \& Tuckett, 2010).

Additionally, other factors such as parental or societal influences on the subject selection (e.g., parents wanting their child to have careers in specific professions such as medicine and law, which can create additional pressure), career-oriented subject selection (e.g., tendency to choose highly demanding or job-securing subjects without prior knowledge), unfavorable learning environments (e.g., unsupportive teacher-student relationships, heavy workload, inferior teaching methods, lack of resources, etc.) may also have a contributory role in mental health suffering (Lee, Wong, Chow, \& McBride-Chang, 2006). Recent studies conducted among university students suggest that these unfavorable academic situations are associated with mental health problems, including depression, anxiety, stress, burnout, adjustment disorders, and suicidality (IsHak et al., 2013; Storrie et al., 2010). Similarly, Bangladeshi studies also suggest that more than half of students are suffering from mental health problems (e.g., Hossain, et al. 2019; Mamun \& Griffiths, 2019a; Mamun et al., 2019a; 2019b; 2019c).

The aforementioned mental health problems are commonly listed as the proximal suicide risk factors (although they can also facilitate distal suicide risk factors) and are major contributory 
factors in suicide completion globally (Brown et al. 2000; Dsouza et al., 2020; Mamun \& Griffiths, 2020a; 2020b). Moreover, Bangladeshi people are more suicide-prone compared to other countries, although figures differ in this respect. Feroz et al. (2012) reported the annual suicide rate in Bangladesh to be 129 per 100,000 population in an suicide prone region, compared to 8 per 100,000 among general people by the World Health Organization (2014). The incidence of student suicide in Bangladesh is thought to be even higher than the general population rate with recent studies reporting five university student suicidality cases within a single 10-day period (Arafat \& Mamun, 2019) and 13 medical and allied health sciences student suicide cases within 23 months (Griffiths et al., 2020; Mamun et al., 2020b). Similarly, other student cohorts' suicide rates are reported by Mamun \& Griffiths (2020d; 2020e) and Mamun et al. (2020c). Moreover, a Bangladeshi retrospective suicide study also suggested that individuals younger than 30 years (arguably, many of who are likely to be students) account for $61 \%$ of total cases (Shah, Ahmed, \& Arafat, 2017) and that $43 \%$ of those attempting suicide are in this cohort [20-29 years; (Feroz et al., 2012)].

To date, only a previous study has investigated suicidal behaviors among Bangladeshi students to the authors' best knowledge (Mamun et al., 2020d). However, suicidality more generally was examined in two earlier studies among adolescents (Begum et al., 2017a) and the general population (Feroz et al., 2012), and there are only a few examining prevalence rates for depression among the students (e.g., Alim et al., 2017; Bhuiyan et al., 2020a; Hossain et al., 2019; Mamun \& Griffiths, 2019a; Mamun et al., 2019a; 2019b; 2019c). However, the role of academic stressor-related factors (e.g., subject selection, learning and academic environment, etc.) in students' mental health have not been investigated in Bangladesh previously, although

such factors have partially been explored in non-Bangladeshi studies, particularly papers that have examined why students change their studies (Cunningham \& Smothers, 2010; Halasz \& Bloom, 2019; Wildman \& Torres, 2002). Consequently, there is a substantial knowledge gap concerning Bangladeshi students' mental health status. Therefore, the present study examined the role of these factors in depression and suicidality.

\section{Methods}

\section{Participants and procedure}

The present cross-sectional study was conducted between September to November 2019 among the Bangladeshi undergraduate and postgraduate students from five different public universities from a total of 53 universities. Of these universalities, two were general in category (e.g., Jahangirnagar University, Dhaka; Jagannath University, Dhaka) and three were science and technology in category (e.g., Jashore University of Science and Technology, Jashore; Mawlana Bhashani Science and Technology University, Tangail; Bangabandhu Sheikh Mujibur Rahman Science \& Technology University, Gopalganj). The universities were purposively selected (two of them were from the capital, Dhaka; the remaining three were from outside of the capital). The data were collected utilizing a 
classroom-based survey, that means the students who were present in the university classrooms at the time of the survey were approached to participate. After getting permission from the university authority, the research team approached the students in between the lecture periods (see 'Measures' section for subjects studied). The research team approached approximately 1,000 students present at the survey time with a printed questionnaire along with the purpose (and related issues) of the study. The self-report survey took approximately 30 minutes to complete, and data from 967 participants were collected. Of these, 960 were retained for the final analysis after removal of incomplete questionnaires (approximate 96\% response rate). Participant's mean age was 21.6 years (SD \pm 1.99 years), and just under half of the participants were female (48.6\%).

\section{Ethical considerations}

The present study adhered to the guidelines of the Helsinki Declaration, 1975. Additionally, the study was approved by the Institute of Allergy and Clinical Immunology of Bangladesh ethics board (IRB No: IRBIACIB/CEC/07201921/300), and additional signed agreements were obtained from the head of respective university departments before data collection. Informed written consent was obtained from the students before participating in the study. They were assured of the anonymity and confidentiality of their data and were provided with information about the nature and purpose of the study, the procedure, and the right to withdraw their data at any time.

\section{Measures}

\section{Sociodemographic variables}

The socio-demographic variables assessed in the present study were age, gender, academic year of study, university location (inside or outside Dhaka; university institutes in Dhaka are highly renowned and well-structured compared to those outside Dhaka), study subject (classified into three possible categories i.e., moderately demanding, very demanding, or extremely demanding based on both media reports [e.g., Hossain, 2017] and the present authors' personal knowledge of the Bangladeshi higher education system). More specifically, moderately demanding: sociology, philosophy, psychology, education, linguistics, Islamic studies, public administration, chemistry, physics, geography; very demanding: English, international relations, law, public health, microbiology, biochemistry and molecular biology; extremely demanding: medicine, engineering, economics, business administration), socio-economic status (i.e., an income less than 15,000 Bangladeshi taka [BDT] for lower class income, 15,000 to 30,000 BDT for middle class income, and more than 30,000 BDT for upper class income based on a previous study [Mamun et al., 2020a; Rafi et al., 2019]), and family type ('nuclear' family or 'joint' [extended] family).

\section{Lifestyle-related variables}

These variables related to whether the participants (i) were cigarette smokers, (ii) preferred to spend time being alone rather than with others, (iii) had engaged in regular religious 
practice, (iv) whether they had experienced any past-year physical suffering, (v) whether they had experienced any past-year mental health suffering, (vi) whether they had experienced any past-year stressful life event, (vii) whether they used social media for more than six hours daily (based on Mamun and colleagues [2019c]), (viii) whether they had been involved in any extra-curricular activities (e.g., debating, event organizing, etc.), and (ix) whether they exercised for more than five hours weekly (Bhamani et al., 2015). All the questions were responded to utilizing a dichotomous response (i.e., yes/no).

\section{Subject selection reasons}

Subject-selection questions were responded to utilizing a dichotomous response (i.e., yes/no). The questions asked concerned their desired institutes or departments, parental influence upon subject selection, subject-related prior knowledge, and career-oriented subject selection (see Table 3 for a list of exact questions asked).

\section{Learning and academic environment}

To examine out if learning and academic environment-related factors (i.e., study/researchfriendly environment, teacher-student relationship, satisfactory academic workloads, etc.) participants were asked to provide one of three responses (i.e., 'extremely', 'moderately' or not at all'). For example, 'Do you have a research-friendly environment?', 'Are you satisfied with the existing curriculum?' (see Table 1 for exact list questions asked).

\section{Bangla Patient Health Questionnaire}

Depression was assessed using the nine-item Bangla Patient Health Questionnaire (Bangla PHQ-9 [Chowdhury et al., 2004]; the original version [Kroenke et al., 2001]). The screening tool is used widely in both non-psychiatric and clinical settings. Symptoms of depression such as depressed mood, sleeping problems, feeling tired, appetite changes, concentration problems, and suicidal thoughts were assessed based on the past two weeks (Kroenke et al., 2001). Items are responded to on a four-point Likert scale $(0=$ not at all, $1=$ several days, $2=$ more than half of the days, and $3=$ nearly every day), and scores range from 0 to 27. Higher scores indicate higher levels of depression, whereas a total of $\geq 10$ is typically used to denote the presence of depression (Mamun et al., 2019d). This cutoff score has an $88 \%$ sensitivity and $88 \%$ specificity of depression (Kroenke et al., 2001). Cronbach's alpha for the present study was very good (0.80).

\section{Suicidal behaviors}

Past year suicidal behaviors were assessed asking the participants if they had thought about committing suicide, whether such thoughts were persistent, and whether there had been any suicide attempts during the past year (Asante et al., 2017; Jahan et al., 2020; Peltzer et al., 2017).

\section{Statistical analysis}


Data were analyzed using Statistical Package for Social Science (SPSS) version 23.0. The descriptive statistics (e.g., frequencies, percentages, means, and chi-squares tests) were performed with SPSS 23.0. All significant variables in the chi-square tests (at $p<0.05$ level) were entered into the binary logistic regression in both unadjusted and adjusted models, with depression and suicidal behaviors as the dependent variables. In the unadjusted model, each risk factor (e.g., gender) was individually used to predict its association with one dependent variable while all the risk factors were included in the adjusted model.

\section{Results}

Four-fifths of the participants (82.1\%) were from nuclear family, and $37.6 \%$ were from families with an upper class income. Two-thirds of the participants were studying at university institutes outside of Dhaka (66.0\%), and most of them were examining moderately demanding subjects (47.3\%). Approximately half of them were depressed (47.7\%), 28.5\% had any type of past-year suicidal behaviors (i.e., suicidal ideation, suicide planning, and/or suicide attempt) (see Table 1).

Females were significantly prone to depression $\left(52.7 \%\right.$ vs. $\left.43.4 \% ; \chi^{2}=8.153, p<0.001\right)$ and suicidal behaviors $\left(35.3 \%\right.$ vs. $\left.22.6 \% ; \chi^{2}=18.855, p<0.001\right)$ compared to males. Other sociodemographic variables including the year of study $\left(\chi^{2}=11.91, p=0.018\right)$, socio-economic status $\left(\chi^{2}=5.94, p=0.05\right)$, and family type $\left(\chi^{2}=6.14, p=0.013\right)$ were significantly associated with suicidal behaviors (Table 1). Participants who preferred living alone reported significantly higher levels of depression $\left(55.6 \%\right.$ vs. $\left.41.0 \% ; \chi^{2}=20.19, p<0.001\right)$ and suicidal behavior $\left(34.5 \%\right.$ vs. $\left.23.8 \% ; \chi^{2}=13.39, p<0.001\right)$ compared to those that did not. Although those who engaged in irregular religious practice (compared to those who were engaged in regular religious practices) were highly depressed ( $54.6 \%$ vs. $\left.43.8 \% ; \chi^{2}=10.60, p<0.001\right)$, they were not significantly associated with suicidal behaviors $\left(\chi^{2}=1.98, p=0.160\right)$. Additionally, depression and suicidal behaviors were significantly associated with past-year physical illness $\left(\chi^{2}=6.33, p=0.012 ; \chi^{2}=5.82, p=0.016\right.$ respectively $)$, mental health illness $\left(\chi^{2}=110.45, p<0.001 ; \chi^{2}=109.18, p<0.001\right.$ respectively $)$, past-year stressful events $\left(\chi^{2}=64.65\right.$, $p<.001 ; \chi^{2}=74.73, p<0.001$ respectively), excessive daily social media use $\left(\chi^{2}=53.72\right.$, $p<.001 ; \chi^{2}=27.64, p<0.001$ respectively], and less weekly physical exercise $\left(\chi^{2}=9.29, p<.001\right.$; $\left.\chi^{2}=4.14, p<0.001\right)$ (Table 2).

In relation to subject selection-related factors, depression and suicidal behaviors were significantly associated with those students not studying in their desired institutions $\left(\chi^{2}=14.94, p<.001 ; \chi^{2}=6.89, p=0.009\right.$ respectively $)$ and selecting their subject purely based on future career prospects (rather than based on what they really wanted to study) $\left(\chi^{2}=8.88\right.$, $p<0.001 ; \chi^{2}=3.83, p=0.05$ respectively) (Table 3 ). In relation to learning and academic environment-related factors, depression and suicidal behaviors were significantly associated with those who were totally dissatisfied with their university institute as the study-friendly environment $\left(\chi^{2}=9.79, p=0.007 ; \chi^{2}=8.562, p=0.014\right.$ respectively), those who were 
dissatisfied with their university institute as a research-friendly environment $\left(\chi^{2}=26.52\right.$, $p<0.001 ; \chi^{2}=7.38, p=0.025$ respectively), and those who were not satisfied with their teachers' supports $\left(\chi^{2}=13.48, p<0.001 ; \chi^{2}=7.309, p=0.026\right.$ respectively $)$. Dissatisfaction with academic workload $\left(\chi^{2}=7.06, p=0.029\right)$ and the existing curriculum $\left(\chi^{2}=13.243, p<0.001\right)$ were only associated with depression (Table 4). Participants having high levels of suicidality (compared to those who had non-suicidal behaviors) were found to have significant depressive symptoms ( $75.2 \%$ vs. $\left.24.8 \% ; \chi^{2}=116.294, p<0.001\right)$ (Figure 1 ).

A binary regression analysis was performed with the significant variables in the bivariate analysis (Table 5 and 6). The models explained 31\% and 28.6\% (Nagelkerke $R^{2}$ ) of the variance in depression and suicidal behaviors and correctly classified $70.6 \%$ and $77.1 \%$ of the cases, respectively. The unadjusted model found that the significant risk factors for both depression and suicidal behavior were female, preferring to spend time alone rather than be with others, suffering from past-year physical illness, mental health illness, and stressful events, using social media more than six hours daily, exercising less than five hours weekly, not studying in their desired university institute, selecting subject by considering their prospective career, and not having a study-friendly environment, not having a researchfriendly environment, and having unsupportive teachers. Additionally, not engaging in religious practice regularly, having no extra-curriculum activities, dissatisfaction with the academic workloads, and dissatisfaction with the existing curriculum were also predictors of depression, whereas being in the first year of academic study, coming from a lower-income or upper-income family (compared to coming from a middle-income family), the nuclear family type was also risk factors for suicidal behaviors.

\section{Discussion}

The role of academic stressor-related factors in contributing to mental health concerns have not been investigated previously among Bangladeshi university students. Therefore, the present study examined the role of these factors concerning depression and suicidal behaviors. The present study was carried out to help to reduce the knowledge gap, provide benchmark data to help promote policymaking within university environments, as well as stimulate further study on this topic both inside and outside Bangladesh.

Recent Bangladeshi studies among university students using convenience samples have reported prevalence rates of $46.3 \%$ to $52.2 \%$ for depression (Hossain et al., 2019; Mamun \& Griffiths, 2019a; Mamun et al., 2019a; 2019b; 2019c). However, the prevalence rates among medical students (54.3\%; (Alim et al., 2017)) and job-seeking graduates (49.3\%; (Rafi et al., 2019)), are typically also higher than other Bangladeshi cohorts (Asghar et al., 2007; Disu et al., 2019; Fitch et al., 2017; Islam et al. 2016; Roy et al., 2012). However, only a very recent study reported the suicidal ideation rate to be $6.9 \%$ for last-month suicidal ideation, whereas $14.7 \%$ and $61.1 \%$ were for past year and lifetime respectively among the Bangabandhu Sheikh Mujibur Rahman Science \& Technology University, Gopalganj students (Mamun et 
al., 2020d). And compared with the present rate (i.e., past year suicidal behaviors to be $28.5 \%$ ), it appears to be double than the previous one. However, a 5\% prevalence rate of lifetime suicidal ideation was reported among Bangladeshi adolescents (Begum et al., 2017a), and a total 35 suicide attempts (16 successful and 19 surviving) were reported among 12,422 individuals from the general population residing in a survey-based community study (Feroz et al., 2012). Based on these figures, it appears that Bangladeshi university students are more prone to mental health illnesses (in this case depression and suicidal behaviors) than other Bangladeshi cohorts, and that preventive action is needed among the university student cohort.

As seen in global trends, females are more likely to suffer from mental health issues (e.g., depression, anxiety, stress, suicidality etc.). In some cases, female mental health suffering can be up to two to three time higher than males (Rosenfield \& Mouzon, 2013) and these findings are consistent with those from the present study. Although females suffer more from mental health problems and suicidal behavior-related issues (i.e., more frequent suicide attempts), they are less likely to commit suicide than males (Bhuiyan et al., 2020b; Dsouza et al., 2020; Mamun \& Ullah, 2020; Mendez-Bustos et al., 2013). However, in Bangladesh, female suicide has been reported to be higher than male suicide (Arafat, 2019). For example, $58 \%$ of the total suicide victims were female among 271 cases (Shah et al., 2017), $60 \%$ out of 358 cases (Arafat, Mali, \& Akter, 2018), and 61.5\% in medicolegal autopsies (48 out of 78 deaths due to hanging [Begum et al., 2017b]). In only two Bangladeshi studies there was a higher suicide rate among male (i.e., 69.2\% out of 334 cases; Ali et al., 2014 and; $71.4 \%$ out of 56 cases; Mamun et al., 2020). Based on the findings of these studies (including the present study), females (and female university students) appear to be particularly vulnerable to persistent mental health-related issues and may require targeted prevention programs.

Loneliness and stressful life-events (that can be changed or determined alongside environmental factors) are associated with depression and suicidal behaviors, and these consequences may result from the interactions of an individual's dysfunctional attitudes with stressful life events that are imposed on such attitudes (Dsouza et al., 2020; Hiramura et al., 2008; Olinger et al., 1987). Fear, worry or anxiety, as well as social withdrawal, dramatic changes in eating or sleeping habits, and loneliness have been associated with accelerated functional decline and increased mental health suffering, and suicidality (Mamun \& Griffiths, 2020e; Scott et al., 2010). These findings are consistent with those of the present study. A recent population-based study utilizing polygenic scores for 27 traits related to behavior, cognition, and mental health showed major depressive disorder, schizophrenia, and bipolar disorder, as well neuroticism and conscientiousness (among the big five personality traits) were significantly associated with loneliness (Abdellaoui et al., 2018). Moreover, psychological suffering and chronic physical health issues (e.g., angina, arthritis, bronchial asthma, hypertension, diabetes, hypothyroidism etc.) were associated with both 
depression and suicidality in the present study, and are consistent with previous literatures (Hiramura et al., 2008; Moussavi et al., 2007; Shah et al., 2018).

Engaging in physical activities such as playing sports, exercising etc. has been shown to reduce depression and suicidal behaviors (Anjum et al., 2019; Bhamani et al., 2015; Disu et al., 2019; Taliaferro et al., 2010). Bhamani and colleagues (2015) reported that individuals who engage in more than 5.2 hours of physical activity weekly were $60 \%$ less likely of developing depression compared to those engaging in two hours of physical activity weekly. Similarly, as reported in a recent meta-analysis, decreased suicidal behavior rates were seen among those actively engaging in physical activities (Vancampfort et al., 2018). Students who were less engaged in physical activities are more likely to be engaged in leisure activities such as social media use. Therefore, it is not surprising that in the present study, those that reported in more than six hours of daily social media were significantly more likely to be suffering from poorer mental health. Previous research has indicated a significant association between excessive internet use (i.e., over 35 hours weekly) and poor mental health wellbeing, including suicidality in some cases ( Chandrima et al., 2020; Kuss et al., 2013; Lin et al., 2014; Mamun et al., 2020a; Mamun \& Griffiths, 2019a; Van der Aa et al., 2009) which is consistent with the findings of the present study.

Globally, university students are typically allowed to change the major subjects (or even change university) due to multifarious reasons (e.g., insufficient prior knowledge during subject selection, being homesick, not finding the subject as interesting as they thought, not coping with course demands after admittance, etc. [Cunningham \& Smothers, 2010; Halasz \& Bloom, 2019; Sklar, 2018; Wildman \& Torres, 2002]). American studies claim that approximately $46 \%-80 \%$ of students change their major subjects once they enroll in universities (Halasz \& Bloom, 2019; Sklar, 2018). However, in Bangladeshi universities, there is very limited scope to rotate or change the major subjects or university. Therefore, students who find their current academic subjects or institutions uninteresting may be unable to cope after the initial stage of their study (i.e., during their first year of study). This was reflected in the present sample because students who were not studying at the universities they really wanted experienced more significant mental health suffering (including suicidality) than those who were studying at their preferred university. However, subject dissatisfaction had no predictive role.

Moreover, issues such as the lack of subject-related prior knowledge can be a factor in why students want to change their primary subject following their initial selection, but Bangladeshi students appear to be guided by subjects that have good career prospects (e.g., high job demand or high salary), and these factors may contribute to mental health suffering (Cunningham \& Smothers, 2010; Wildman \& Torres, 2002). However, insufficient knowledge of the subject chosen was not a predictor of mental health problems in the present study, but choosing a subject based on career prospects was. If students are choosing 
topics based on what they think will do best for their career rather than intrinsically liking the subject under study, it is not surprising that some students will not like what they are studying and suffer mental health issues as a consequence.

Although university education in Bangladesh has improved since the early 2000s, quality assurance systems can be haphazard (HEQEP, 2017). On the surface, rapid growth in facilities for more innovative teaching methods (e.g., multimedia classrooms, online-based course content) is evident in Bangladeshi universities. Many universities use the presence of these facilities as a reason to attract students but university teachers are still teaching the curricula in traditional ways and not necessarily using these facilities (HEQEP, 2017). Furthermore, there is a little scope for student feedback in universities who have an orthodox grading system, non-operational equipment, and outdated curriculum (World Bank, 2019), factors that have been associated with student satisfaction. Many governmentaffiliated universities do no update their curricula or include relevant transferable skills which may undermine students' critical thinking ability and the functionality of their acquired degree (Economist Intelligence Unit, 2014). Such a situation may mediate mental health issues. An unsupportive student-teacher relationship was also a risk factor for depression and suicidality in the present study. This may be because the teachers are following a traditional way of teaching (e.g., printed sheet-based lessons, written assessments without involving practical knowledge, etc.) that are non-creative in which students become apathetic to participating actively in high-level critical thinking and related problem-solving (Economist Intelligence Unit, 2014; World Bank, 2014).

Consequently, the country is replete with universities that have a lack of technical training facilities leading to poorly skilled graduates that are not ready to enter the job market. Recent figures by the Labour Force Survey 2016-17 show that the unemployment rate among university graduates is three times higher than the national average rate of Bangladesh (World Bank, 2019). Therefore, the tertiary education system in Bangladesh is highly unfavorable for students, and the aforementioned factors (i.e., dissatisfaction with university institute not being a study-friendly or research-friendly environment, dissatisfaction with teacher support, heavy academic workload, etc.) were highly associated with mental health consequences in the present study. Therefore, it is recommended that university authorities develop focused strategies and enhance infrastructure to help facilitate better student wellbeing.

The present findings are limited due to the cross-sectional nature of the study as well as other common methodological issues (i.e., convenience sampling, self-report data, selfselected sample, etc.). Participants might have completed the questionnaire in a socially desirable way on sensitive issues like suicide ideation. Moreover, no particular established scale was used to elicit the past-year suicidal behavior. The present study did not differentiate between 'subject selection' and 'subject selection reasons'. Such 'reasons' are 
embedded within a dynamic process, and the study had limited these two categories with binary responses. Similarly, was the approach to 'learning environment'. Therefore, there is a need to distinguish between them so that interventions can be enhanced in future studies. Furthermore, only public university students in Bangladesh were included in this study. Purposive selection of the public universities might mean the findings cannot be generalized to other Bangladeshi universities. Thus, further studies targeting different educational institutions (e.g., private universities, medical colleges, nursing colleges etc.) and educational backgrounds are needed to better understand the factors. Finally, future longitudinal studies are needed to help identify the causal factors leading to psychological distress.

\section{Practical implications}

The present study is the first to provide baseline data concerning depression and suicidality relating to the role of subject selection reasons and learning environment-related factors in Bangladesh. Most importantly it can be noted that the studied academic distress related issues are the prominent suicide risk factor among Bangladeshi students (Arafat \& Mamun, 2019; Mamun \& Griffiths, 2020b; 2020c; 2020d; Mamun et al., 2020b; 2020c), whereas the present findings have implications for universities and government bodies who may want to modify processes in such a way to assist in healthy student wellbeing. A multidisciplinary approach is recommended whereby structures can be set up help psychiatrists to work closely with universities. Engineering, medical and nursing colleges need to be more proactive in identifying, preventing and treating the mental health suffering among Bangladeshi students. 


\section{References}

Abdellaoui, A., Nivard, M. G., Hottenga, J., Fedko, I., Verweij, K. J. H., Baselmans, B. M. L., ... Boomsma, D. I. (2018). Predicting loneliness with polygenic scores of social, psychological and psychiatric traits. Genes, Brain and Behavior, 17(6), e12472.

Ali, E., Maksud, M., Zubyra, S. J., Hossain, M. S., Debnath, P. R., Alam, A., \& Chakrabarty, P. K. (2014). Suicide by hanging: A study of 334 cases. Bangladesh Medical Journal, 43(2), 90-93.

Alim, S. M. A. H. M., Rabbani, M. G., Karim, E., Mullick, M. S. I., Al Mamun, A., \& Khan, M. Z. R. (2017). Assessment of depression, anxiety and stress among first year MBBS students of a public medical college, Bangladesh. Bangladesh Journal of Psychiatry, 29(1), 23-29.

Anjum, A., Hossain, S., Sikder, T., Uddin, M. E., \&, \& Rahim, D. A. (2019). Investigating the prevalence of and factors associated with depressive symptoms among urban and semi-urban school adolescents in Bangladesh: A pilot study. International Health, Epub ahead of print. https://doi.org/10.1093/inthealth/ihz092

Arafat, S. M. Y. (2019). Females are dying more than males by suicide in Bangladesh. Asian Journal of Psychiatry, 40, 124-125.

Arafat, S. M. Y., Mali, B., \& Akter, H. (2018). Demography and risk factors of suicidal behavior in Bangladesh: A retrospective online news content analysis. Asian Journal of Psychiatry, 36, 96-99.

Arafat, S. M. Y., \& Mamun, M. A. A. (2019). Repeated suicides in the University of Dhaka (November 2018): Strategies to identify risky individuals. Asian Journal of Psychiatry, 39, 84-85.

Asante, K. O., Kugbey, N., Osafo, J., Quarshie, E. N.-B., \& Sarfo, J. O. (2017). The prevalence and correlates of suicidal behaviours (ideation, plan and attempt) among adolescents in senior high schools in Ghana. SSM-Population Health, 3, 427-434.

Asghar, S., Hussain, A., Ali, S. M. K., Khan, A. K. A., \& Magnusson, A. (2007). Prevalence of depression and diabetes: A population based study from rural Bangladesh. Diabet Med, 24, 872-877.

Begum, Afroza, Rahman, A. K. M. F., Rahman, A., Soares, J., Reza Khankeh, H., \& Macassa, G. (2017a). Prevalence of suicide ideation among adolescents and young adults in rural Bangladesh. International Journal of Mental Health, 46(3), 177-187.

Begum, Asma, Khan, N. T., Shafiuzzaman, A. K. M., Shahid, F., Anam, A. M. A., Ahmed, K. S., ... Fahmi, S. (2017b). Suicidal death due to hanging. Delta Medical College Journal, 5(2), 89-93.

Bhamani, M. A., Khan, M. M., Karim, M. S., \& Mir, M. U. (2015). Depression and its association with functional status and physical activity in the elderly in Karachi, Pakistan. Asian Journal of Psychiatry, 14, 46-51.

Bhuiyan, M. A. H., Griffiths, M. D., \& Mamun, M. A. (2020a). Depression literacy among Bangladeshi preuniversity students: Differences based on gender, educational attainment, depression, and anxiety. Asian Journal of Psychiatry, 50, e101944.

Bhuiyan, A. I., Sakib, N., Pakpour, A. H., Griffiths, M. D., \& Mamun, M. A. (2020b). COVID-19-related suicides in Bangladesh due to lockdown and economic factors: Case study evidence from media reports. International Journal of Mental Health and Addiction, Epub ahead of print. DOI: 10.1007/s11469-020-00307y.

Billah, M. (2019). Discrimination between public and private university students. Retrieved January 9, 2020, from https://www.daily-sun.com/printversion/details/398840/2019/06/13/Discrimination-betweenpublic-and-private-university-students

Brown, G. K., Beck, A. T., Steer, R. A., \& Grisham, J. R. (2000). Risk factors for suicide in psychiatric outpatients: A 20-year prospective study. Journal of Consulting and Clinical Psychology, 68(3), 371.

Chandrima, R. M., Kircaburun, K., Kabir, H., Riaz, B. K., Kuss, D. J., Griffiths, M. D., \& Mamun, M. A. (2020). Adolescent problematic internet use and parental mediation: A Bangladeshi structured interview study. Addictive Behaviors Reports, 12, e100288.

Chowdhury, A. N., Ghosh, S., \& Sanyal, D. (2004). Bengali adaptation of brief patient health questionnaire for screening depression at primary care. Journal of the Indian Medical Association, 102(10), 544-547.

Cunningham, K. E., \& Smothers, A. W. (2010). The effect of self-efficacy and psychosocial development on major-changing behavior. NACADA Journal, 30(2), 65-71.

Disu, T. R., Anne, N. J., Griffiths, M. D., \& Mamun, M. A. (2019). Risk factors of geriatric depression among elderly Bangladeshi people: A pilot interview study. Asian Journal of Psychiatry, 44, 163-169.

Dsouza, D. D., Quadros, S., Hyderabadwala, Z. J., \& Mamun, M. A. (2020). Aggregated COVID-19 suicide

12 | P a g e 
incidences in India: Fear of COVID-19 infection is the prominent causative factor. Psychiatry Research, 290, e113145.

Economist Intelligence Unit. (2014). High university enrolment, low graduate employment: Analysing the paradox in Afghanistan, Bangladesh, India, Nepal, Pakistan and Sri Lanka. Retrieved January 9, 2020, from https://www.britishcouncil.in/sites/default/files/british_council_report_2014_jan.pdf

Feroz, A. H. M., Islam, S. M. N., Reza, S., Rahman, A. K. M. M., Sen, J., Mowla, M., \& Rahman, M. R. (2012). A community survey on the prevalence of suicidal attempts and deaths in a selected rural area of Bangladesh. Journal of Medicine, 13(1), 3-9.

Fitch, T. J., Moran, J., Villanueva, G., Sagiraju, H. K. R., Quadir, M. M., \& Alamgir, H. (2017). Prevalence and risk factors of depression among garment workers in Bangladesh. International Journal of Social Psychiatry, 63(3), 244-254.

Griffiths, M. D., \& Mamun, M. A. (2020). COVID-19 suicidal behavior among couples and suicide pacts: Case study evidence from press reports. Psychiatry Research, 289, e113105.

Griffiths, M. D., Misti, J. M., \& Mamun, M. A. (2020). Bangladeshi medical students' suicide: A response to Arafat (2020). Asian Journal of Psychiatry, 53, e102201.

Halasz, H. M., \& Bloom, J. L. (2019). Major Adjustment: Undergraduates' Transition Experiences When Leaving Selective Degree Programs. NACADA Journal, 39(1), 77-88.

HEQEP. (2017). A Brief Report on Satisfaction Survey 2016: Higher Education Quality Enhancement Project. Dhaka, BD.

Hiramura, H., Shono, M., Tanaka, N., Nagata, T., \& Kitamura, T. (2008). Prospective study on suicidal ideation among Japanese undergraduate students: Correlation with stressful life events, depression, and depressogenic cognitive patterns. Archives of Suicide Research, 12(3), 238-250.

Hossain, M. A. (2017). Job-oriented subjects getting priority in higher education. Daily Sun, March 21. Retrieved July 30, 2020, from https://www.dailysun.com/printversion/details/213763/2017/03/21/Joboriented-subjects-getting-priority-in-highereducation

Hossain, S., Anjum, A., Uddin, M. E., Rahman, M. A., \& Hossain, M. F. (2019). Impacts of socio-cultural environment and lifestyle factors on the psychological health of university students in Bangladesh: A longitudinal study. Journal of Affective Disorders, 256, 393-403.

IsHak, W., Nikravesh, R., Lederer, S., Perry, R., Ogunyemi, D., \& Bernstein, C. (2013). Burnout in medical students: a systematic review. The Clinical Teacher, 10(4), 242-245.

Islam, M. A., Rahman, A., Aleem, M. A., \& Islam, S. M. S. (2016). Prevalence and associated factors of depression among post-stroke patients in Bangladesh. International Journal of Mental Health and Addiction, 14(2), 154-166.

Jahan, S., Araf, K., Griffiths, M. D., Gozal, D., \& Mamun, M. A. (2020). Depression and suicidal behaviors among Bangladeshi mothers of children with Autism Spectrum Disorder: A comparative study. Asian Journal of Psychiatry, 51, e101994.

Kroenke, K., Spitzer, R. L., \& Williams, J. B. W. (2001). The PHQ- 9: Validity of a brief depression severity measure. Journal of General Internal Medicine, 16(9), 606-613.

Kuss, D. J., Griffiths, M. D., \& Binder, J. F. (2013). Internet addiction in students: Prevalence and risk factors. Computers in Human Behavior, 29(3), 959-966.

Lee, M. T. Y., Wong, B. P., Chow, B. W.-Y., \& McBride-Chang, C. (2006). Predictors of suicide ideation and depression in Hong Kong adolescents: Perceptions of academic and family climates. Suicide and LifeThreatening Behaviorehavior, 36(1), 82-96.

Lin, I.-H., Ko, C.-H., Chang, Y.-P., Liu, T.-L., Wang, P.-W., Lin, H.-C., ... Yen, C.-F. (2014). The association between suicidality and Internet addiction and activities in Taiwanese adolescents. Comprehensive Psychiatry, 55(3), 504-510.

Mamun, M. A., Akter, S., Hossain, I., ... \& Griffiths, M. D. (2020a). Financial threat, hardship and distress predict depression, anxiety and stress among the unemployed youths: A Bangladeshi multi-cities study. Journal of Affective Disorders, Epub ahead of print. DOI: 10.1016/j.jad.2020.06.075.

Mamun, M. A., \& Griffiths, M. (2019a). The association between Facebook addiction and depression: A pilot survey study among Bangladeshi students. Psychiatry Research, 271, 628-633.

Mamun, M. A., \& Griffiths, M. D. (2020a). PTSD-related suicide six years after the Rana Plaza collapse in Bangladesh. Psychiatry Research, 287, e112645.

Mamun, M. A., \& Griffiths, M. D. (2020b). A rare case of Bangladeshi student suicide by gunshot due to 
unusual multiple causalities. Asian Journal of Psychiatry, 49, e101951.

Mamun, M. A., \& Griffiths, M. D. (2020c). Young teenage suicides in Bangladesh-are mandatory Junior School Certificate exams to blame?. International Journal of Mental Health and Addiction, Epub ahead of print. DOI: 10.1007/s11469-020-00275-3.

Mamun, M. A., \& Griffiths, M. D. (2020d). Mandatory Junior School Certificate exams and young teenage suicides in Bangladesh: A response to Arafat (2020). International Journal of Mental Health and Addiction, Epub ahead of print. DOI: 10.1007/s11469-020-00324-x.

Mamun, M. A, Hossain, M. S., \& Griffiths, M. D. (2019a). Mental health problems and associated predictors among Bangladeshi students. International Journal of Mental Health and Addiction, Epub ahead of print. DOI: 10.1007/s11469-019-00144-8.

Mamun, M. A, Hossain, M. S., Siddique, A. B., Sikder, M. T., Kuss, D. J., \& Griffiths, M. D. (2019b). Problematic internet use in Bangladeshi students: The role of socio-demographic factors, depression, anxiety, and stress. Asian Journal of Psychiatry, 44, 48-54.

Mamun, M. A., Huq, N., Papia, Z. F., Tasfina, S., \& Gozal, D. (2019d). Prevalence of depression among Bangladeshi village women subsequent to a natural disaster: A pilot study. Psychiatry Research, 276, 124128.

Mamun, M. A., Misti, J. M., \& Griffiths, M. D. (2020b). Suicide of Bangladeshi medical students: Risk factor trends based on Bangladeshi press reports. Asian Journal of Psychiatry, 48, e101905.

Mamun, M. A., Rafi, A. M., Al Mamun, A. H. M. S., ... Griffiths, M. D. (2019c). Prevalence and psychiatric risk factors of excessive internet use among northern Bangladeshi job-seeking graduate students: A pilot study. International Journal of Mental Health and Addiction, Epub ahead of print. DOI:10.1007/s11469-01900066-5.

Mamun, M. A., Rayhan, I., Akter, K., \& Griffiths, M. D. (2020d). Prevalence and predisposing factors of suicidal ideation among the university students in Bangladesh: A single-site survey. International Journal of Mental Health and Addiction, Epub ahead of print.

Mamun, M. A., Siddique, A. B., Sikder, M. T., \& Griffiths, M. D. (2020c). Student suicide risk and gender: A retrospective study from Bangladeshi press reports. International Journal of Mental Health and Addiction, Epub ahead of print. DOI:10.1007/s11469-020-00267-3.

Mamun, M. A., \& Ullah, I. (2020). COVID-19 suicides in Pakistan, dying off not COVID-19 fear but poverty? - The forthcoming economic challenges for a developing country. Brain, Behavior, and Immunity, 87, 163166.

Mendez-Bustos, P., Lopez-Castroman, J., Baca-García, E., \& Ceverino, A. (2013). Life cycle and suicidal behavior among women. The Scientific World Journal, 2013, e485851.

Moussavi, S., Chatterji, S., Verdes, E., Tandon, A., Patel, V., \& Ustun, B. (2007). Depression, chronic diseases, and decrements in health: results from the World Health Surveys. Lancet, 370. 851-858.

Olinger, L. J., Kuiper, N. A., \& Shaw, B. F. (1987). Dysfunctional attitudes and stressful life events: An interactive model of depression. Cognitive Therapy and Research, 11(1), 25-40.

Peltzer, K., Yi, S., \& Pengpid, S. (2017). Suicidal behaviors and associated factors among university students in six countries in the Association of Southeast Asian Nations (ASEAN). Asian Journal of Psychiatry, 26, 32-38.

Rafi, M. A., Mamun, M. A., Hsan, K., Hossain, M., \& Gozal, D. (2019). Psychological implications of unemployment among Bangladesh Civil Service job seekers: A pilot study. Frontiers in Psychiatry, 10, e578.

Rosenfield, S., \& Mouzon, D. (2013). Gender and mental health. In Handbook of the sociology of mental health (pp. 277-296). Springer.

Roy, T., Lloyd, C. E., Parvin, M., Mohiuddin, K. G. B., \& Rahman, M. (2012). Prevalence of co-morbid depression in out-patients with type 2 diabetes mellitus in Bangladesh. BMC Psychiatry, 12(1), e123.

Shah, M. M. A., Ahmed, S., \& Arafat, S. M. Y. (2017). Demography and risk factors of suicide in Bangladesh: a six-month paper content analysis. Psychiatry Journal, 2017, Article ID 3047025.

Shah, M. M. A., Sajib, M. W. H., \& Arafat, S. M. Y. (2018). Demography and risk factor of suicidal behavior in Bangladesh: A cross-sectional observation from patients attending a suicide prevention clinic of Bangladesh. Asian Journal of Psychiatry, 35, 4-5.

Sklar, J. C. (2018). Event history analysis for investigating the likelihood and timing of changing majors. NACADA Journal, 38(1), 47-60.

Storrie, K., Ahern, K., \& Tuckett, A. (2010). A systematic review: students with mental health problems-a 
growing problem. International Journal of Nursing Practice, 16(1), 1-6.

Taliaferro, L. A., Rienzo, B. A., \& Donovan, K. A. (2010). Relationships between youth sport participation and selected health risk behaviors from 1999 to 2007. Journal of School Health, 80(8), 399-410.

Trines, S. (2019). Education in Bangladesh. Retrieved January 9, 2020, from https://wenr.wes.org/2019/08/education-in-bangladesh/

Van der Aa, N., Overbeek, G., Engels, R. C. M. E., Scholte, R. H. J., Meerkerk, G.-J., \& Van den Eijnden, R. J. J. M. (2009). Daily and compulsive internet use and well-being in adolescence: a diathesis-stress model based on big five personality traits. Journal of Youth and Adolescence, 38(6), 765.

Vancampfort, D., Hallgren, M., Firth, J., Rosenbaum, S., Schuch, F. B., Mugisha, J., ... Stubbs, B. (2018). Physical activity and suicidal ideation: A systematic review and meta-analysis. Journal of Affective Disorders, 225, 438-448.

WHO. (2014). Preventing suicide: A global imperative. Retrieved from https://apps.who.int/iris/bitstream/handle/10665/131056/9789241564779-ger.pdf

Wildman, M. L., \& Torres, R. M. (2002). Factors influencing choice of major in agriculture. NACTA Journal, $4-9$.

World Bank. (2014). A study on national university and affiliated colleges in Bangladesh. Retrieved January 9 , 2020,

from http://documents.worldbank.org/curated/en/942041468209656122/pdf/844280NWP0BD0U00Box38 2120B00PUBLIC0.pdf

World Bank. (2019). Bangladesh tertiary education sector review: Skills and innovation for growth. Retrieved January 9, 2020, from http://documents.worldbank.org/curated/en/303961553747212653/BangladeshTertiary-Education-Sector-Review-Skills-and-Innovation-for-Growth 
Figure 1: Cluster analysis of depression on suicidality

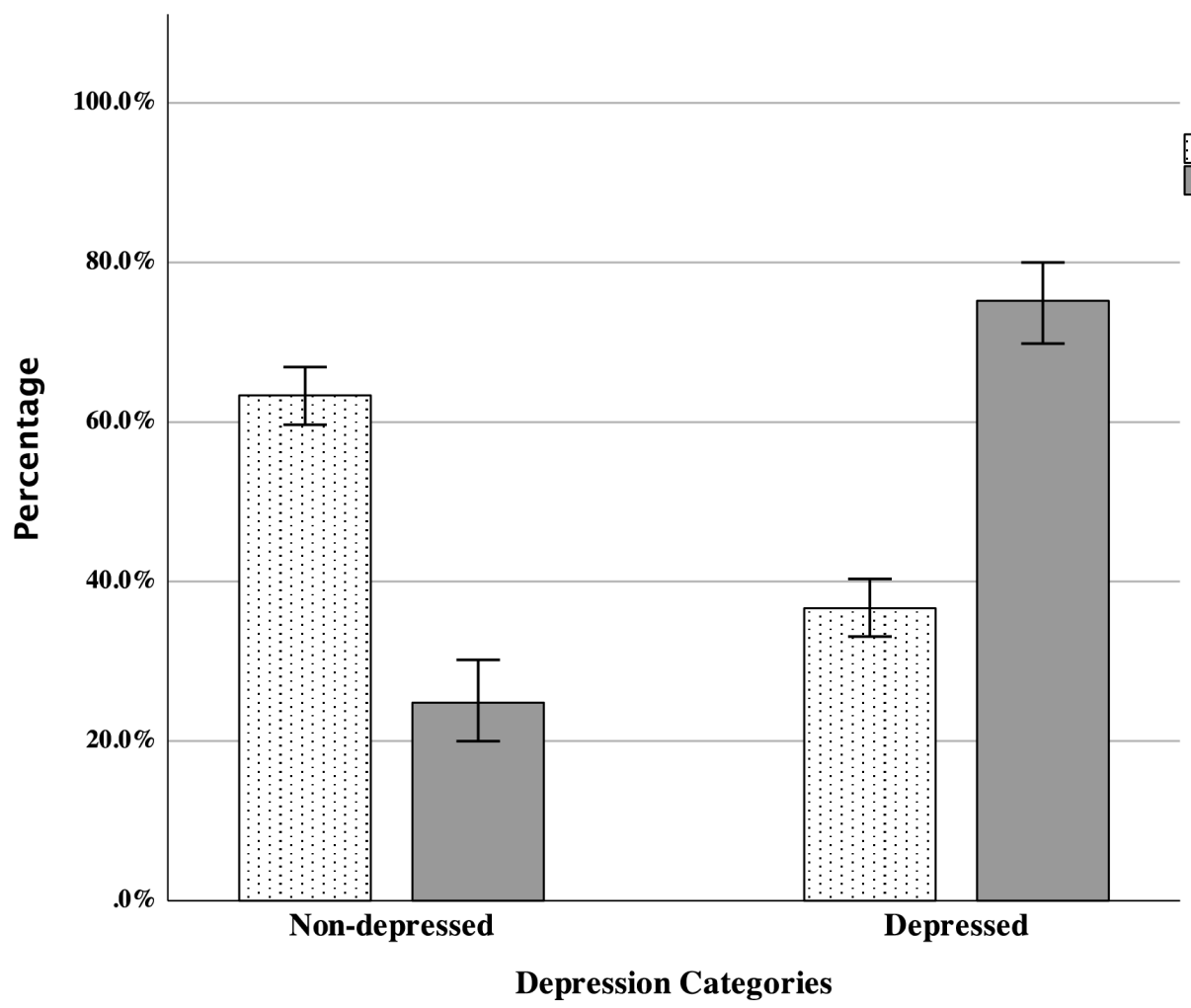

Suicidality

Non-Suicidal Behavior

Suicidal behavior

Error bars: $95 \%$ CI 
Table 1. Distribution of the socio-demographic variables with depression and suicidal behavior

\begin{tabular}{|c|c|c|c|c|c|c|c|}
\hline \multirow[t]{2}{*}{ Variables } & \multirow[t]{2}{*}{ Total; $n(\%)$} & \multicolumn{3}{|c|}{ Depression $(458 ; 47.7 \%)$} & \multicolumn{3}{|c|}{ Suicidal behavior $(274 ; 28.5 \%)$} \\
\hline & & $n(\%)$ & $X^{2}$ test value & $p$-value & $n(\%)$ & $X^{2}$ test value & $p$-value \\
\hline \multicolumn{8}{|l|}{ Gender } \\
\hline Female & $467 ; 48.6$ & $246 ; 52.7$ & \multirow[t]{2}{*}{8.153} & \multirow[t]{2}{*}{$<0.001$} & $164 ; 35.3$ & \multirow[t]{2}{*}{18.855} & \multirow[t]{2}{*}{$<0.001$} \\
\hline Male & $488 ; 50.8$ & $212 ; 43.4$ & & & $110 ; 22.6$ & & \\
\hline \multicolumn{8}{|l|}{ Year of study } \\
\hline $1^{\text {st }}$ year & $254 ; 26.5$ & $131 ; 51.6$ & \multirow[t]{5}{*}{5.459} & \multirow[t]{5}{*}{0.243} & $87 ; 34.5$ & \multirow[t]{5}{*}{11.905} & \multirow[t]{5}{*}{0.018} \\
\hline $2^{\text {nd }}$ year & $258 ; 26.9$ & $128 ; 49.6$ & & & $81 ; 31.6$ & & \\
\hline $3^{\text {rd }}$ year & $214 ; 22.3$ & $95 ; 44.4$ & & & $55 ; 25.7$ & & \\
\hline $4^{\text {th }}$ year & $154 ; 16.0$ & $69 ; 44.8$ & & & $39 ; 25.3$ & & \\
\hline Postgraduate & $67 ; 7.0$ & $26 ; 38.8$ & & & $11 ; 16.4$ & & \\
\hline \multicolumn{8}{|l|}{ Institute location } \\
\hline Inside capital city & $299 ; 31.1$ & $143 ; 47.8$ & \multirow[t]{2}{*}{0.010} & \multirow[t]{2}{*}{0.920} & $81 ; 27.2$ & \multirow[t]{2}{*}{0.275} & \multirow[t]{2}{*}{0.600} \\
\hline Outside capital city & $634 ; 66.0$ & $301 ; 47.5$ & & & $182 ; 28.8$ & & \\
\hline \multicolumn{8}{|c|}{ Study subject (based on job demand) } \\
\hline $\begin{array}{l}\text { Moderately } \\
\text { demanding }\end{array}$ & $294 ; 30.6$ & $137 ; 46.6$ & \multirow[t]{3}{*}{2.182} & \multirow[t]{3}{*}{0.336} & $84 ; 28.7$ & \multirow[t]{3}{*}{1.348} & \multirow[t]{3}{*}{0.510} \\
\hline Very demanding & $454 ; 47.3$ & $210 ; 46.3$ & & & $124 ; 27.4$ & & \\
\hline $\begin{array}{l}\text { Extremely } \\
\text { demanding }\end{array}$ & $205 ; 21.4$ & $107 ; 52.2$ & & & $65 ; 31.9$ & & \\
\hline \multicolumn{8}{|c|}{ Socio-economic status } \\
\hline Lower class income & $223 ; 23.2$ & $101 ; 45.3$ & \multirow[t]{3}{*}{0.581} & \multirow[t]{3}{*}{0.748} & $60 ; 26.9$ & \multirow[t]{3}{*}{5.943} & \multirow[t]{3}{*}{0.05} \\
\hline Middle class income & $340 ; 35.4$ & $164 ; 48.2$ & & & $86 ; 25.6$ & & \\
\hline Upper class income & $361 ; 37.6$ & $174 ; 48.2$ & & & $121 ; 33.5$ & & \\
\hline \multicolumn{8}{|l|}{ Family type } \\
\hline Nuclear & $788 ; 82.1$ & $376 ; 47.7$ & \multirow[t]{2}{*}{0.027} & \multirow[t]{2}{*}{0.870} & $238 ; 30.4$ & \multirow[t]{2}{*}{6.136} & 0.013 \\
\hline Joint & $168 ; 17.5$ & $79 ; 47.0$ & & & $35 ; 20.8$ & & \\
\hline
\end{tabular}

Table 2. Distribution of the life-style related variables with depression and suicidal behavior

\begin{tabular}{|c|c|c|c|c|c|c|c|}
\hline \multirow[t]{2}{*}{ Variables } & \multirow[t]{2}{*}{ Total; $\boldsymbol{n}(\%)$} & \multicolumn{3}{|c|}{ Depression $(458 ; 47.7 \%)$} & \multicolumn{3}{|c|}{ Suicidal behavior $(274 ; 28.5 \%)$} \\
\hline & & $n(\%)$ & $X^{2}$ test value & $p$-value & $n(\%)$ & $\begin{array}{l}X^{2} \text { test } \\
\text { value }\end{array}$ & $p$-value \\
\hline \multicolumn{8}{|c|}{ Life-style related variables } \\
\hline \multicolumn{8}{|c|}{ Cigarette smoker } \\
\hline Yes & $124 ; 12.9$ & $69 ; 55.6$ & \multirow[t]{2}{*}{3.467} & \multirow[t]{2}{*}{0.063} & $32 ; 26.0$ & \multirow[t]{2}{*}{0.538} & \multirow[t]{2}{*}{0.463} \\
\hline No & $831 ; 86.6$ & $388 ; 46.7$ & & & $242 ; 29.2$ & & \\
\hline \multicolumn{8}{|c|}{ Prefer being alone } \\
\hline Yes & $448 ; 46.7$ & $249 ; 55.6$ & \multirow[t]{2}{*}{20.191} & \multirow[t]{2}{*}{$<0.001$} & $154 ; 34.5$ & \multirow[t]{2}{*}{13.386} & \multirow[t]{2}{*}{$<0.001$} \\
\hline No & $507 ; 52.8$ & $208 ; 41.0$ & & & $120 ; 23.8$ & & \\
\hline \multicolumn{8}{|c|}{ Engaging regularly in religious practice } \\
\hline Yes & $601 ; 62.6$ & $263 ; 43.8$ & \multirow[t]{2}{*}{10.602} & \multirow[t]{2}{*}{$<0.001$} & $162 ; 27.1$ & \multirow[t]{2}{*}{1.978} & \multirow[t]{2}{*}{0.160} \\
\hline No & $355 ; 37.0$ & $194 ; 54.6$ & & & $111 ; 31.4$ & & \\
\hline
\end{tabular}




\begin{tabular}{|c|c|c|c|c|c|c|c|}
\hline \multicolumn{8}{|c|}{ Physical illness in past year } \\
\hline Yes & $82 ; 8.5$ & $50 ; 61.0$ & \multirow[t]{2}{*}{6.332} & \multirow[t]{2}{*}{0.012} & $33 ; 40.2$ & \multirow[t]{2}{*}{5.818} & \multirow{2}{*}{0.016} \\
\hline No & $876 ; 91.3$ & $407 ; 46.5$ & & & $241 ; 27.6$ & & \\
\hline \multicolumn{8}{|c|}{ Mental health illness in past year } \\
\hline Yes & $314 ; 32.7$ & $226 ; 72.0$ & \multirow[t]{2}{*}{110.454} & \multirow[t]{2}{*}{$<0.001$} & $159 ; 50.6$ & \multirow[t]{2}{*}{109.184} & \multirow[t]{2}{*}{$<0.001$} \\
\hline No & $642 ; 66.9$ & $230 ; 35.8$ & & & $115 ; 18.0$ & & \\
\hline \multicolumn{8}{|c|}{ Stressful life events in past year } \\
\hline Yes & $770 ; 49.0$ & $286 ; 60.9$ & \multirow[t]{2}{*}{64.645} & \multirow[t]{2}{*}{$<0.001$} & $195 ; 41.8$ & \multirow[t]{2}{*}{74.729} & \multirow[t]{2}{*}{$<0.001$} \\
\hline No & $480 ; 50.0$ & $167 ; 34.8$ & & & $78 ; 16.3$ & & \\
\hline \multicolumn{8}{|c|}{ Social media use (more than six hours daily) } \\
\hline Yes & $359 ; 37.4$ & $226 ; 63.0$ & \multirow[t]{2}{*}{53.721} & \multirow[t]{2}{*}{$<0.001$} & $138 ; 38.5$ & \multirow[t]{2}{*}{27.644} & \multirow[t]{2}{*}{$<0.001$} \\
\hline No & $595 ; 62.0$ & $229 ; 38.5$ & & & $134 ; 22.6$ & & \\
\hline \multicolumn{8}{|c|}{ Extra-curricular university activities } \\
\hline Yes & $446 ; 46.5$ & $198 ; 44.4$ & \multirow[t]{2}{*}{4.015} & \multirow[t]{2}{*}{0.045} & $129 ; 29.1$ & \multirow[t]{2}{*}{0.037} & \multirow[t]{2}{*}{0.847} \\
\hline No & $511 ; 53.2$ & $260 ; 50.9$ & & & $145 ; 28.5$ & & \\
\hline \multicolumn{8}{|c|}{ Weekly physical exercise } \\
\hline Less than five hours & $851 ; 88.6$ & $421 ; 49.5$ & \multirow[t]{2}{*}{9.293} & \multirow[t]{2}{*}{$<0.001$} & $252 ; 29.8$ & \multirow[t]{2}{*}{4.136} & \multirow[t]{2}{*}{0.043} \\
\hline More than five hours & $104 ; 10.8$ & $35 ; 33.7$ & & & $21 ; 20.2$ & & \\
\hline
\end{tabular}

Table 3. Distribution of the subject selection reasons variables with depression and suicidal behavior

\begin{tabular}{|c|c|c|c|c|c|c|c|}
\hline \multirow[t]{2}{*}{ Variables } & \multirow[t]{2}{*}{ Total; $\boldsymbol{n}(\%)$} & \multicolumn{3}{|c|}{ Depression $(458 ; 47.7 \%)$} & \multicolumn{3}{|c|}{ Suicidal behavior $(274 ; 28.5 \%)$} \\
\hline & & $n(\%)$ & $X^{2}$ test value & $p$-value & $n(\%)$ & $\begin{array}{l}X^{2} \text { test } \\
\text { value }\end{array}$ & $p$-value \\
\hline \multicolumn{8}{|c|}{ Subject selection reasons } \\
\hline \multicolumn{8}{|c|}{ Are you studying in your desired university institution? } \\
\hline Yes & $323 ; 33.6$ & $126 ; 39.0$ & \multirow[t]{2}{*}{14.942} & \multirow[t]{2}{*}{$<0.001$} & $75 ; 23.2$ & \multirow[t]{2}{*}{6.886} & \multirow[t]{2}{*}{0.009} \\
\hline No & $636 ; 66.3$ & $332 ; 52.2$ & & & $198 ; 31.3$ & & \\
\hline \multicolumn{8}{|c|}{ Are you studying in your desired department/subject? } \\
\hline Yes & $426 ; 44.4$ & $192 ; 45.1$ & \multirow[t]{2}{*}{1.967} & \multirow[t]{2}{*}{0.161} & $124 ; 29.1$ & \multirow[t]{2}{*}{.134} & \multirow[t]{2}{*}{0.714} \\
\hline No & $532 ; 55.4$ & $264 ; 49.6$ & & & $148 ; 28.0$ & & \\
\hline \multicolumn{8}{|c|}{ Did you face any parental influence in your subject selection? } \\
\hline Yes & $283 ; 29.5$ & $147 ; 51.9$ & \multirow[t]{2}{*}{2.762} & \multirow[t]{2}{*}{0.097} & $94 ; 33.2$ & \multirow[t]{2}{*}{3.863} & \multirow[t]{2}{*}{0.049} \\
\hline No & $673 ; 70.1$ & $310 ; 46.1$ & & & $180 ; 26.9$ & & \\
\hline \multicolumn{8}{|c|}{ Did you have any subject related prior knowledge? } \\
\hline Yes & $584 ; 60.8$ & $266 ; 45.5$ & \multirow[t]{2}{*}{3.062} & \multirow[t]{2}{*}{0.080} & $163 ; 28.1$ & \multirow[t]{2}{*}{0.322} & \multirow[t]{2}{*}{0.570} \\
\hline No & $374 ; 39.0$ & $192 ; 51.3$ & & & $111 ; 29.8$ & & \\
\hline \multicolumn{8}{|c|}{ Did you select the subject due to career prospects only? } \\
\hline Yes & $445 ; 46.4$ & $235 ; 52.8$ & \multirow[t]{2}{*}{8.878} & \multirow[t]{2}{*}{$<0.001$} & $141 ; 31.8$ & \multirow[t]{2}{*}{3.826} & \multirow[t]{2}{*}{0.050} \\
\hline No & $512 ; 53.3$ & $221 ; 43.2$ & & & $133 ; 26.1$ & & \\
\hline
\end{tabular}


Table 4. Distribution of the learning and academic environment variables with depression and suicidal behavior

\begin{tabular}{|c|c|c|c|c|c|c|c|}
\hline \multirow[t]{2}{*}{ Variables } & \multirow[t]{2}{*}{ Total; $n(\%)$} & \multicolumn{3}{|c|}{ Depression (458; 47.7\%) } & \multicolumn{3}{|c|}{ Suicidal behavior $(274 ; 28.5 \%)$} \\
\hline & & $n(\%)$ & $X^{2}$ test value & $p$-value & $n(\%)$ & $\begin{array}{l}X^{2} \text { test } \\
\text { value }\end{array}$ & $p$-value \\
\hline \multicolumn{8}{|c|}{ Do you have a study-friendly environment? } \\
\hline Extremely & $347 ; 36.1$ & $145 ; 41.8$ & \multirow[t]{3}{*}{9.791} & \multirow[t]{3}{*}{0.007} & $86 ; 24.9$ & \multirow[t]{3}{*}{8.562} & \multirow[t]{3}{*}{0.014} \\
\hline Moderately & $448 ; 46.7$ & $222 ; 49.6$ & & & $127 ; 28.5$ & & \\
\hline Not at all & $163 ; 17.0$ & $91 ; 55.8$ & & & $61 ; 37.4$ & & \\
\hline \multicolumn{8}{|c|}{ Are your university teachers supportive? } \\
\hline Extremely & $439 ; 45.7$ & $185 ; 42.1$ & \multirow[t]{3}{*}{13.481} & \multirow[t]{3}{*}{$<0.001$} & $114 ; 26.0$ & \multirow[t]{3}{*}{7.309} & \multirow[t]{3}{*}{0.026} \\
\hline Moderately & $371 ; 38.6$ & $185 ; 49.9$ & & & $104 ; 28.3$ & & \\
\hline Not at all & $146 ; 15.2$ & $86 ; 58.9$ & & & $55 ; 37.7$ & & \\
\hline \multicolumn{8}{|c|}{ Do you have a research-friendly environment? } \\
\hline Extremely & $277 ; 28.9$ & $98 ; 35.4$ & \multirow[t]{3}{*}{26.524} & \multirow[t]{3}{*}{$<0.001$} & $63 ; 22.8$ & \multirow[t]{3}{*}{7.376} & \multirow[t]{3}{*}{0.025} \\
\hline Moderately & $300 ; 31.3$ & $148 ; 49.3$ & & & $89 ; 29.8$ & & \\
\hline Not at all & $278 ; 39.4$ & $210 ; 55.6$ & & & $122 ; 32.4$ & & \\
\hline \multicolumn{8}{|c|}{ Are you satisfied with the academic workload (i.e. presentations, assignments, tutorials)? } \\
\hline Extremely & $662 ; 69.0$ & $302 ; 45.6$ & \multirow[t]{3}{*}{7.058} & \multirow[t]{3}{*}{0.029} & $186 ; 28.2$ & \multirow[t]{3}{*}{1.352} & \multirow[t]{3}{*}{0.509} \\
\hline Moderately & $171 ; 17.8$ & $84 ; 49.1$ & & & $55 ; 32.4$ & & \\
\hline Not at all & $123 ; 12.8$ & $72 ; 58.5$ & & & $33 ; 27.0$ & & \\
\hline \multicolumn{8}{|c|}{ Are you satisfied with the existing curriculum? } \\
\hline Extremely & $156 ; 16.3$ & $71 ; 45.5$ & \multirow[t]{3}{*}{13.243} & \multirow[t]{3}{*}{$<0.001$} & $49 ; 31.4$ & \multirow[t]{3}{*}{1.475} & \multirow[t]{3}{*}{0.478} \\
\hline Moderately & $306 ; 31.9$ & $122 ; 39.9$ & & & $80 ; 26.4$ & & \\
\hline Not at all & $156 ; 16.3$ & $261 ; 52.9$ & & & $145 ; 29.5$ & & \\
\hline
\end{tabular}

Table 5. Logistic regression analysis of the variables with depression

\begin{tabular}{|c|c|c|c|c|c|c|}
\hline \multirow[t]{2}{*}{ Variables } & \multicolumn{3}{|c|}{ Unadjusted model } & \multicolumn{3}{|l|}{ Adjusted model } \\
\hline & $\begin{array}{l}\text { Odds ratio } \\
\text { (OR) }\end{array}$ & $\begin{array}{l}\text { 95\% Confidence } \\
\text { Interval (CI) }\end{array}$ & $p$-value & $\begin{array}{l}\text { Adjusted odds } \\
\text { ratio (AOR)* }\end{array}$ & $\begin{array}{l}\text { 95\% Confidence } \\
\text { Interval (CI) }\end{array}$ & $p$-value \\
\hline \multicolumn{7}{|l|}{ Gender } \\
\hline Female & 1.449 & $1.123-1.870$ & \multirow{2}{*}{0.004} & 1.350 & $0.978-1.863$ & \multirow{2}{*}{0.068} \\
\hline Male & \multicolumn{2}{|l|}{ Reference } & & \multicolumn{2}{|l|}{ Reference } & \\
\hline \multicolumn{7}{|c|}{ Prefer being alone } \\
\hline Yes & 1.799 & $1.391-2.326$ & \multirow{2}{*}{$<0.001$} & 1.147 & $0.838-1.571$ & \multirow{2}{*}{0.392} \\
\hline No & \multicolumn{2}{|l|}{ Reference } & & & \\
\hline \multicolumn{7}{|c|}{ Engaging regularly in religious practice } \\
\hline Yes & 0.646 & $0.496-0.841$ & \multirow[t]{2}{*}{0.001} & 0.898 & $0.653-1.236$ & \multirow[t]{2}{*}{0.510} \\
\hline No & Reference & & & & & \\
\hline \multicolumn{7}{|c|}{ Physical illness in past year } \\
\hline Yes & 1.801 & $1.133-2.861$ & \multirow[t]{2}{*}{0.013} & 1.176 & $0.686-2.016$ & \multirow{2}{*}{0.555} \\
\hline No & Reference & & & & & \\
\hline \multicolumn{7}{|c|}{ Mental health illness in past year } \\
\hline Yes & 4.00 & $3.427-6.175$ & \multirow{2}{*}{$<0.001$} & 3.508 & $2.461-5.002$ & \multirow{2}{*}{$<0.001$} \\
\hline No & \multicolumn{2}{|l|}{ Reference } & & \multicolumn{2}{|l|}{ Reference } & \\
\hline
\end{tabular}




\begin{tabular}{|c|c|c|c|c|c|c|}
\hline Yes & 2.913 & $2.238-3.793$ & \multirow[t]{2}{*}{$<0.001$} & 2.113 & $1.548-2.883$ & \multirow[t]{2}{*}{$<0.001$} \\
\hline No & \multicolumn{2}{|c|}{ Reference } & & \multicolumn{2}{|c|}{ Reference } & \\
\hline \multicolumn{7}{|c|}{ Social media use (more than six hours daily) } \\
\hline Yes & 2.716 & $2.072-3.559$ & \multirow[t]{2}{*}{$<0.001$} & 2.390 & $1.740-3.283$ & \multirow[t]{2}{*}{$<0.001$} \\
\hline No & \multicolumn{2}{|c|}{ Reference } & & \multicolumn{2}{|c|}{ Reference } & \\
\hline \multicolumn{7}{|c|}{ Extra-curricular university activities } \\
\hline Yes & 0.771 & $0.597-0.995$ & \multirow[t]{2}{*}{0.045} & 0.815 & $0.596-1.113$ & \multirow[t]{2}{*}{0.198} \\
\hline No & \multicolumn{2}{|c|}{ Reference } & & \multicolumn{2}{|l|}{ 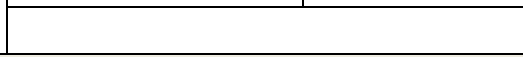 } & \\
\hline \multicolumn{7}{|c|}{ Weekly physical exercise } \\
\hline Less than five hours & 1.930 & $1.258-2.962$ & \multirow[t]{2}{*}{0.003} & 2.136 & $1.280-3.564$ & \multirow[t]{2}{*}{0.004} \\
\hline More than five hours & \multicolumn{2}{|c|}{ Reference } & & & \\
\hline \multicolumn{7}{|c|}{ Are you studying in your desired university institution? } \\
\hline Yes & 0.586 & $0.446-0.769$ & \multirow[t]{2}{*}{$<0.001$} & 0.697 & $0.501-0.970$ & \multirow[t]{2}{*}{0.032} \\
\hline No & \multicolumn{2}{|c|}{ Reference } & & & \\
\hline \multicolumn{7}{|c|}{ Did you select the subject due to career prospects only? } \\
\hline Yes & 1.473 & $1.141-1.902$ & \multirow[t]{2}{*}{0.003} & 1.577 & $0.849-1.577$ & \multirow[t]{2}{*}{0.356} \\
\hline No & Refere & & & Refere & & \\
\hline Do you have a study- & endly e & iment? & & & & \\
\hline No & 1.761 & $1.209-2.563$ & 0.008 & 0.945 & $0.566-1.577$ & 0.587 \\
\hline Average & 1.368 & $1.032-1.815$ & & 1.156 & $0.804-1.663$ & \\
\hline Yes & Refere & & & Refere & & \\
\hline Are your university $t$ & hers su & ive? & & & & \\
\hline Not at all & 1.968 & $1.345-2.878$ & $<0.001$ & 1.114 & $0.651-1.905$ & 0.811 \\
\hline Moderately & 1.366 & $1.034-1.803$ & & 0.945 & $0.651-1.372$ & \\
\hline Extremely & Refere & & & Refere & & \\
\hline Do you have a resear & friendl & ronment? & & & & \\
\hline Not at all & 2.283 & $1.659-3.141$ & $<0.001$ & 1.476 & $0.961-2.268$ & 0.174 \\
\hline Moderately & 1.778 & $1.273-2.485$ & & 1.382 & $0.910-2.099$ & \\
\hline Extremely & Refere & & & Refere & & \\
\hline Are you satisfied wit & he acad & workload (i.e. & entation & assign & rials)? & \\
\hline Not at all & 1.683 & $1.139-2.486$ & 0.031 & 1.484 & $0.896-2.458$ & 0.306 \\
\hline Moderately & 1.151 & $0.822-1.611$ & & 1.049 & $0.692-1.589$ & \\
\hline Extremely & Refere & & & Refere & & \\
\hline Are you satisfied wit & he exist & irriculum? & & & & \\
\hline Not at all & 1.347 & $0.938-1.933$ & 0.001 & 0.946 & $0.587-1.526$ & 0.032 \\
\hline Moderately & 0.794 & $0.538-1.172$ & & 0.607 & $0.374-0.986$ & \\
\hline Extremely & Refere & & & Refere & & \\
\hline
\end{tabular}

${ }^{*} A O R$ for included explanatory factors: adjusted with all the variables significant 
Table 6. Logistic regression analysis of the variables with suicidal behavior

\begin{tabular}{|c|c|c|c|c|c|c|}
\hline \multirow[t]{2}{*}{ Variables } & \multicolumn{3}{|c|}{ Unadjusted model } & \multicolumn{3}{|l|}{ Adjusted model } \\
\hline & $\begin{array}{l}\text { Odds ratio } \\
\text { (OR) }\end{array}$ & \begin{tabular}{|l} 
95\% Confidence \\
Interval (CI)
\end{tabular} & $\begin{array}{l}p- \\
\text { value }\end{array}$ & $\begin{array}{l}\text { Adjusted odds } \\
\text { ratio (AOR)* }\end{array}$ & $\begin{array}{l}\text { 95\% Confidence } \\
\text { Interval (CI) }\end{array}$ & $p$-value \\
\hline \multicolumn{7}{|l|}{ Gender } \\
\hline Female & 1.874 & $1.409-2.492$ & \multirow[t]{2}{*}{$<0.001$} & 1.580 & $1.112-2.245$ & \multirow[t]{2}{*}{0.011} \\
\hline Male & \multicolumn{2}{|l|}{ Reference } & & \multicolumn{2}{|l|}{ Reference } & \\
\hline \multicolumn{7}{|l|}{ Year of study } \\
\hline $1^{\text {st }}$ year & 2.684 & $1.338-5.387$ & \multirow{5}{*}{0.021} & 4.521 & $1.952-10.470$ & \multirow[t]{5}{*}{0.002} \\
\hline $2^{\text {nd }}$ year & 2.356 & $1.172-4.736$ & & 2.770 & $1.214-6.320$ & \\
\hline $3^{\text {rd }}$ year & 1.761 & \begin{tabular}{|l|}
$0.861-3.601$ \\
\end{tabular} & & 2.638 & $1.134-6.135$ & \\
\hline $4^{\text {th }}$ year & 1.726 & $0.823-3.624$ & & 2.003 & $0.842-4.762$ & \\
\hline Post-graduate & \multicolumn{2}{|l|}{ Reference } & & \multicolumn{2}{|l|}{ Reference } & \\
\hline \multicolumn{7}{|l|}{ Socio-economic status } \\
\hline Lower class income & 1.370 & $0.948-1.979$ & \multirow{3}{*}{0.052} & 1.274 & $0.823-1.973$ & \multirow{3}{*}{0.126} \\
\hline Middle class income & 0.935 & $0.636-1.372$ & & 0.853 & $0.545-1.335$ & \\
\hline Upper class income & \multicolumn{2}{|l|}{ Reference } & & \multicolumn{2}{|l|}{ Reference } & \\
\hline \multicolumn{7}{|l|}{ Family type } \\
\hline Nuclear & 1.656 & $1.108-2.477$ & \multirow{2}{*}{0.014} & 1.759 & \begin{tabular}{|l|}
$1.077-2.873$ \\
\end{tabular} & \multirow[t]{2}{*}{0.024} \\
\hline Joint & \multicolumn{2}{|l|}{ Reference } & & \multicolumn{2}{|l|}{ Reference } & \\
\hline Prefer being alone & & & & & & \\
\hline Yes & 1.692 & $1.275-2.246$ & $<0.001$ & 1.123 & $0.792-1.592$ & 0.515 \\
\hline No & Reference & & & Reference & & \\
\hline Physical illness in th & ast year & & & & & \\
\hline Yes & 1.763 & $1.107-2.809$ & 0.017 & 1.202 & $0.696-2.076$ & 0.510 \\
\hline No & Reference & & & Reference & & \\
\hline Mental health illnes & the past yea & & & & & \\
\hline Yes & 4.665 & $3.458-6.294$ & $<0.001$ & 3.447 & $2.395-4.961$ & $<0.001$ \\
\hline No & Reference & & & Reference & & \\
\hline Stressful life events & ing the past & & & & & \\
\hline Yes & 3.686 & $2.718-4.997$ & $<0.001$ & 2.854 & $2.002-4.068$ & $<0.001$ \\
\hline No & Reference & & & Reference & & \\
\hline Social media use (mc & than six hou & daily) & & & & \\
\hline Yes & 2.144 & $1.609-2.857$ & $<0.001$ & 1.558 & $1.103-2.201$ & 0.012 \\
\hline No & Reference & & & Reference & & \\
\hline Weekly physical exe & & & & & & \\
\hline Less than five hours & 1.674 & $1.014-2.762$ & 0.044 & 1.520 & $0.859-2.688$ & 0.150 \\
\hline More than five hours & Reference & & & Reference & & \\
\hline Are you studying in & ir desired un & ersity institution? & & & & \\
\hline Yes & 0.663 & $0.487-0.902$ & 0.009 & 0.791 & $0.539-1.160$ & 0.230 \\
\hline No & Reference & & & Reference & & \\
\hline Did you have any & tal influence & your subject & ction? & & & \\
\hline Yes & 1.351 & $1.00-1.825$ & 0.050 & 1.194 & $0.828-1.722$ & 0.343 \\
\hline No & Reference & & & Reference & & \\
\hline Did you select the & ct due to car & r prospects only? & & & & \\
\hline Yes & 1.323 & $0.999-1.753$ & 0.051 & 01.116 & $0.788-1.581$ & 0.537 \\
\hline No & Reference & & & Reference & & \\
\hline
\end{tabular}




\begin{tabular}{|c|c|c|c|c|c|c|}
\hline \multicolumn{7}{|c|}{ Do you have a study-friendly environment? } \\
\hline Not at all & 1.808 & $1.212-2.698$ & \multirow[t]{3}{*}{0.015} & 1.277 & $0.740-2.202$ & \multirow[t]{3}{*}{0.647} \\
\hline Moderately & 1.207 & $0.878-1.661$ & & 1.040 & $0.691-1.566$ & \\
\hline Extremely & \multicolumn{2}{|c|}{ Reference } & & \multicolumn{2}{|c|}{ Reference } & \\
\hline \multicolumn{7}{|c|}{ Are your university teachers supportive? } \\
\hline Not at all & 1.718 & $1.155-2.555$ & \multirow[t]{3}{*}{0.027} & 1.051 & $1.051-3.187$ & \multirow[t]{3}{*}{0.057} \\
\hline Moderately & 1.120 & $0.820-1.529$ & & 1.004 & $0.668-1.509$ & \\
\hline Extremely & \multicolumn{2}{|c|}{ Reference } & & \multicolumn{2}{|c|}{ Reference } & \\
\hline \multicolumn{7}{|c|}{ Do you have a research-friendly environment? } \\
\hline Not at all & 1.624 & $1.139-2.315$ & \multirow[t]{3}{*}{0.026} & 1.065 & $0.657-1.728$ & \multirow[t]{3}{*}{0.449} \\
\hline Moderately & 1.433 & $0.985-2.084$ & & 1.028 & $0.646-1.637$ & \\
\hline Extremely & \multicolumn{2}{|c|}{ Reference } & & \multicolumn{2}{|c|}{ Reference } & \\
\hline
\end{tabular}

${ }^{*} A O R$ for included explanatory factors: adjusted with all the variables significant 